\title{
OLDSAGSKOMMISSIONEN I KØBENHAVN OG OLDSAGSSAMLINGEN I KIEL
}

\author{
ET STYKKE DANSK-TYSK MUSEUMSHISTORIE \\ AF \\ M. MACKEPRANG \\ DR. PHIL., DIREKTøR FOR NATIONALMUSEET, KøBENHAVN \\ *
}

edenstaaende lille Skitse, der næsten helt bygger paa Aktstykker i National-
museets Arkiv, har ikke til Hensigt at give de to Institutioners Barndomsog Ungdomshistorie. Dens Formaal har ene været at skildre deres indbyrdes Forhold i en Periode, hvor Forudsætningerne for den gamle dansk-tyske Helstat brister, at vise hvorledes Tilstanden, selv paa Tider, hvor Bølgerne gik højest, ikke har været en „Alles Krig mod Alle“, men at der selv da har været smaa, fredfyldte Oaser, hvor det gamle venskabelige Samarbejde mellem de to Nationer fortsattes.

Den 22. Maj r8o7 nedsattes Den kgl. Kommission til Oldsagers Opbevaring, der først ophævedes I849, og hvis Hovedværk blev „Museet for de nordiske Oldsager", „Oldnordisk Museum“, Kærnen i det nuværende Nationalmuseum. Navnlig efter at den 28-aarige Købmand og Samler Christian Jürgensen Thomsen I8I6 var bleven dens Sekretær, tog Udviklingen Fart. Museet blev fra 1819 tilgængeligt for Publikum, og i dets Nyopstilling gennemførte Thomsen først af alle den Tredeling i Sten-, Bronce- og Jærnalder, der senere gik sin Sejersgang Verden over. Ogsaa Samlingerne voksede stærkt, men geografisk set var Genstandenes Fordeling saare ujævn. Museet skulde efter sit Program omfatte hele det daværende Monarki og havde da ogsaa saavel før som i de nærmeste Aar efter 1814 modtaget en Del Sager fra Norge - senere ogsaa fra Island -, hvorimod Hertugdømmerne var meget sparsomt repræsenterede. Af de c. 3200 Numre, Samlingen omfattede ved Udgangen af i83I, stammer kun 5 pCt. fra disse Dele af Monarkiet, nemlig 70 Numre fra Slesvig, go fra Holsten. Selvom der mellem dem fandtes saa anseelige Stykker som den store, af Brüggeman skaarne St. Jørgen fra Husum og to Altertavler fra Preetz, var der unægtelig 
her et Misforhold tilstede, og den Maade, Kommissionen søgte at raade Bod herpaa, bærer Vidne om den ideelle Tankegang, der laa bag dens hele Virke i disse Aar. Dens Hovedformaal var jo efter Kommissoriet fra 1807 at sørge for Oldsagernes „Opbevaring“, og vilde Bjærget ikke komme til Muhamed, maatte Muhamed komme til Bjærget!

Paa sit Møde d. 31. Juli 183 I besluttede den derfor „at virke til, at en offentlig Samling af nordiske Oldsager indrettedes for begge Hertugdømmerne om mulig i Kiel " samt i den Anledning at sætte sig i Forbindelse med Professor Falck ,som en med de forskjellige Forhold i Hertugdømmerne bekjendt Mand"1. Officielt stilledes Forslaget af Kommissionens Formand, den stærkt videnskabelig interesserede Overhofmarskal A. W. Hauch, dets Ophavsmand var dog Thomsen, der allerede i Forvejen stod i Forbindelse med Falck og fra dansk Side blev den drivende Kraft i Arbejdet ${ }^{2}$. Som Sekretær paahvilede det ham at affatte den officielle Henvendelse til Falck, men selvom man ikke havde vidst dette, vilde man kunne læse det ud af følgende Passus, der er saare karakteristisk for det Syn paa Museumsvirksomheden, han aldrig blev træt af at gentage:

Da man hier aus Erfahrung reden kann, so glaubt die Commission äussern zu dürfen, dass es bei weitem nicht bloss Geld ist, was die Sache befördern würde, sondern dass es von weit grösserer Wichtigkeit ist, Männer zu finden, welche sich der Aufbewahrung und Erhaltung der Alterthümer annehmen wollen und können, und die auf Anderen in den verschiedenen Gegenden des Landes zu wirken wissen.

Forøvrig gjorde han opmærksom paa, at man antagelig vilde kunne faa den lille Oldsagssamling, „Det patriotiske Selskab“ havde i Altona, ligesom han stillede Dubletter i Udsigt fra Kommissionens egen Samling ${ }^{3}$.

Hos Falck faldt Tanken i god Jord, og i Efteraaret 1831 indsendte han en Skrivelse til Kommissionen, i hvilken han foreslog, at der skulde dannes et Selskab med Sæde i Kiel og med en foreløbig Bestyrelse, der foruden af ham selv skulde bestaa af Professorerne Flor, Paulsen og Twesten og Oldsamleren Kammerherre, Overvejinspektør Warnstedt i Plön. Selskabet skulde i det hele tage sig af Fortidsminderne i Hertugdømmerne og oprette en Samling, der skulde være offentlig tilgængelig, og for hvilken man skulde ansøge Kongen om nogle Værelser paa Slottet 4 .

1 Kom. Mødeprotokol. 2 Dette fremgaar bl. a. af det nedenfor citerede Brev til Kammerherre Warnstedt. ${ }^{3}$ Sept. 1831. Kom. Brevbog II, $248 \mathrm{f}$. ' Falcks Brev findes ikke i Kommissionens i det hele ikke altfor velbevarede Arkiv, men kendes fra et udførligt Referat i Mødeprotokollen for $1832 \%$, jfr. Cirkul. af $1831 \%$ 
Kommissionen fandt i det hele Forslagene „ligesaa hensigtsmæssige som nyttige", men gjorde opmærksom paa det uheldige i, at Samlingen tilhørte et privat Selskab, og raadede derfor til, at man fra første Færd skulde betone, at den var "det offentliges Ejendom“. I Overensstemmelse hermed fastslog de endelige Statutter da ogsaa, at Samlingerne skulde betragtes som et „Pertinens“ til Universitetsbibliotheket i Kiel. De Mænd, Falck havde udpeget til den midlertidige Bestyrelse, „anseer Kommissionen for meget heldigt valgte og lover sig af deres Bestræbelser de bedste Følger". Endelig gentog den nu i bindende Form sit Løfte om, naar Indsamlingen af Oldsager var paabegyndt, „ved en Suite af Doubletter at kunne bidrage til Forøgelsen af en Samling, som den ønsker al mulig Fremgang "1. Skrivelsen havde forøvrig givet Anledning til et lille Intermezzo, som der vil være saa meget mere Grund til at omtale lidt nærmere, som det er det eneste i sin Art. Da Thomsen var utilfreds med sin Koncept, havde han ikke forinden Cirkulationen villet sørge for, at den blev oversat paa „rigtigt Tydsk", hvortil et Medlem af Kommissionen, Bispen og Historikeren Peter Erasmus Müller, imidlertid bemærkede: „Mig synes, at det hverken er nødvendigt eller passende at tilskrive Etatsraad Falck paa Tydsk, da denne meget godt forstaar det danske. " 2 Som Følge heraf afgik Skrivelsen paa Dansk, ligesom den senere Korrespondance i d. m. delvis er ført paa dette Sprog.

Forsaavidt var alt i Orden, men der skulde dog endnu hengaa et Par Aars Tid, inden Selskabet officielt traadte i Virksomhed. Uvist hvorfor synes man en Tid lang at have ligget stille i Kiel, men ved en Rejse, Overhofmarskal Hauch i Sommeren 1833 foretog i Hertugdømmerne, er som Thomsen skrev ,den længe paatænkte Sag atter kommen paa Bane og vil blive udført“3. Kommissionen indhentede derfor Kongens Tilladelse til, at de tidligere lovede Dubletter, i alt o. 300 Stykker, afgaves til Selskabet, der takket være Hauch nu fik indrømmet et Par Værelser i Overappellationsrettens Bygning, og fra Fonden ad usus publicos stilledes der 500 Rdlr. til Raadighed for Samlingernes Installering 4 . Alligevel kunde man ikke komme i Gang. En Ansøgning, man havde indsendt til det slesvig-holstenske Kancelli om kgl. Approbation paa Statutterne, lod dette nemlig ganske rolig ligge et Aars Tid, og før den forelaa, kunde man ikke udsende de offentlige Indbydelser til Selskabets Stiftelse. I et Brev til Thomsen fra Foraaret 1834 klager Flor sin bitre Nød. Selv kunde han ikke henvende

1 Skr. af $183224 / 3$ i Brevbog II, 259 f. Cirkul. af $7 / 3$ 1832. 3 Cirkul. $183319 / 10^{\circ}$ 4 Afgivelsen: Kgl. Resol. af $183312 / 1{ }^{\text {. }}$ - Lokale og Tilskud: Skr. fra Flor af 1834 18/s jfr. Erster Bericht d. Kgl. Schlesw.-Holst.-Lauenb. Gesellsch. f. d. Samml. u. Erhaltung vaterl. Alterth., S. 2. 
sig til Kancelliets I. Deputerede, Frederik VI's højtbetroede Mand, den almægtige Høpp, „da jeg er meget ilde anskreven hos denne Mand, saa at jeg maaske snarere vilde skade end gavne. “ Han havde derfor „hyppig plaget" saavel Falck som Universitetets Curator Jensen „om at purre Høpp“, men hidtil havde dette ikke hjulpet. Samme Dag, den I8. Marts, som Flor udstødte dette Nødraab, havde Kancelliet imidlertid taget sig sammen og sendt Kommissionen Statutterne til Erklæring. Dennes Udtalelse aandede kun Velvilje. „Med Glæde, " skrev den, havde den set sit Ønske om Oprettelsen af en frivillig Forening gaa i Opfyldelse, hvorfor den paa „det varmeste“ anbefalede Sagen til Kancelliet ${ }^{1}$. Den 27. Maj forelaa da endelig den allerhøjeste Stadfæstelse af Statuttet for „Die königliche Schleswig-Holstein-Lauenburgische Gesellschaft für die Sammlung und Erhaltung vaterländischer Alterthümer", som Selskabets officielle Navn kom til at lyde, og i Efteraaret og Vinteren begyndte Hvervningen af Medlemmer, der lykkedes saa godt, at man i Løbet af et Aars Tid naaede det efter Datidens Forhold anseelige Antal af 366 , hvoraf 25 i København, væsentlig Embedsmænd, Officerer og Videnskabsmænd, deriblandt næsten alle Kommissionens Medlemmer ${ }^{2}$. Museet, hvis Grundstamme foruden af Kommissionens Gave bestod af den ret anseelige Oldsagssamling, Kammerherre Warnstedt tidligere havde skænket Selskabet, opstilledes i Sommeren I835, og paa den første ordinære Generalforsamling i Januar 1836 valgtes den endelige Bestyrelse. Bortset fra Professor Twesten, der som bortflyttet erstattedes med Historikeren Professor A. Michelsen, kom den til at bestaa af de Mænd, der havde udgjort det forberedende Arbejdsudvalg. Falck blev selvfølgelig Formand; mere overraskende er det, at Chr. Paulsen blev Kasserer og Flor Sekretær, i hvilken Egenskab han havde Opsyn med Samlingerne. Tilmed blev han et af de tre Medlemmer, der valgtes paa Livstid ${ }^{3}$. Paa os virker det ejendommeligt at se disse to Navne Side om Side ikke blot med den i national Henseende relativt fredsommelige Falck, men ogsaa med Balemann, Ridderskabets Sekretær, og Michelsen, „Augustenborgernes statsretslige Sagfører", som A. D. Jørgensen har kaldt ham. Man maa imidlertid ikke glemme, at endnu ved Midten af Tredverne var det, der bandt, stærkere end det der skilte, og at netop dengang havde den nye Stænderforfatning, som Ørsted senere skriver, vakt en Erkendelse af, „at

1 Brevbog II, $308 \mathrm{f}$. Det kan bemærkes, at den nedenfor omtalte kgl. Reservation vedrørende Danefæ ikke er fremkommen paa Foranledning af Kommissionen, men er en simpel Konsekvens af, at Danefæ betragtedes som et kgl. Regale. ' 2 I. Bericht, S. 2-3, jfr. Medlemslisten. Det kan nævnes, at saavel Kronprinsen som Hertugen af Augustenborg var Medlemmer. ${ }^{3}$ r. Bericht, S. 5-6. 
det paa den nye Bane var nødvendigt at søge alt bortfjernet, som kunde være $i$ Vejen for en samdrægtig Virken"1. Snarere kan man undre sig over, at Samarbejdet kunde vedblive, efterat de nationale Modsætninger i Fyrrerne var traadt klart og skarpt frem. Paulsen blev imidlertid ved med at være Kasserer og forestaa Selskabets Møntsamling lige til I848, og da Flor I844 forlod Kiel, bragte hans Kolleger ham en varm Tak:

Die Gesellschaft verdankt ihm die ganze innere, so viele Zeit und Mühe kostende, Einrichtung und Ordnung des Museums, so dass es sein Werk genannt werden kann. Mit der grössten Uneigennützigkeit hat er auf vielen Reisen den Zwecken der Gesellschaft gedient, oder eigends deswegen manche unternommen; auch unterhielt er theils dadurch, theils brieflich eine beständige Verbindung mit unseren bedeutendsten Alterthumsforschern (namentlich dem Herrn Justizrath Jaspersen in Nordskov und Herrn Etatsrath Thomsen in Kopenhagen). Sein Verlust ist daher schwer zu ersetzen ${ }^{2}$.

Om det daglige Samarbejde just har formet sig saa helt ideelt, som man efter disse Ord maatte formode, er dog vist tvivlsomt. Allerede i et Privatbrev til Thomsen fra Vinteren 1835 klager Flor stærkt over, at det er ham, der maa trække hele Læsset, og tilføjer: „Hertil kommer, at jeg i Grunden (Tand for Tunge!) er som Secretair meget ilde lidt baade af Falck og Warnstedt, hvilket, al Politik fra min Side uagtet, er uundgaaeligt, da Aarsagen er vore forskjellige Anskuelser om vores første Pligt, som jeg anseer for at være at frelse, bevare, ordne o.s. v. alle Landets Antiquit.; de andre to derimod for at udtale vore Formodninger om disse og andre Antiquiteter. "3 Dette er jo imidlertid saglige Modsætninger, som heller ikke var ukendte i København, og hvad de nationale angaar, har de $\mathrm{i}$ hvert Fald ikke, hverken direkte eller indirekte, sat sig Spor i den Privatkorrespondance, der førtes mellem Thomsen, Flor og Paulsen. Den er altid af hel saglig Art, og naar det kommer højt, kan Paulsen paa en - naturligvis tysk - officiel Skrivelse til Thomsen tilføje: „En dansk Hilsen foruden dette ved Siden af andre skrevne Embeds Brev!"4

Til Oldsagskommissionen i København vedblev Forholdet lige til I848 at være det bedste, og i dens Sekretær havde det nye Museum en klog, hjælpsom og uegennyttig Ven. Den største Tjeneste gjorde han det vistnok under Starten, da man i Kiel tænkte paa at ansøge om at faa Oldnordisk Museums Sager fra Hertugdømmerne udleverede. Denne, heller ikke i vore Dage ukendte Maade at oprette Museer paa, fraraadede Thomsen indtrængende. Et saadant Andragende,

1 Danmarks Riges Hist. VI, I, S. 214-15. 2 I I. Bericht, S. 26. En lignende Tak til Paulsen, „der in Folge der Ereignisse des vorigen Jahres Kiel zu verlassen sich bewogen fand“ (!) i 14. Bericht, S. 32 . ${ }^{3}$ Thomsens Breve i Nationalmuseets Arkiv. ' Skr. af 1843 3/3. 
skriver han til Kammerherre Warnstedt $\mathrm{i}$ et ogsaa for hans københavnske Museumsplaner vigtigt Brev, vil „strax i Begyndelsen sætte ondt Blod og vil dog intet Væsentligt nytte, men maaske forhindre Planer, som jeg har for Fremtiden og som vilde være langt vigtigere. Jorden, Moserne, Kirkelofterne, de gl. Herregaarde, Raritets- og Curiositetssamlingerne, dér har De de rige Skatkamre, hvorfra den vordende Samling skal danne sig, og rører(!) man sig hensigtmæssigst og forstaaer at vinde Publicums Yndest, da skal De kun see, at disse Kilder ere uudtømmelige“. De „Planer“, hvortil han hentydede, var hans kære, stadige Tanke, en Indlemmelse af det gamle Kunstkammers Sager fra Oldtid og Middelalder i Oldnordisk Museum. Sker dette, fortsætter han, ,giver jeg Dem at betænke, om der ikke ved den Leilighed kunde, naar de stod dem godt med os, være en ganske anderledes Fangst at gjøre"1. Men ogsaa direkte hjalp han dem under Starten, og det var med fuld Føje, at Kieler Selskabet sluttede den Skrivelse, med hvilken det oversendte ham deres Hverveopraab, med følgende varmtfølte Ord:

Ew. Wohlgeboren haben die Güte gehabt, unserm Unternehmen eine so ausgezeichnete thätige Theilnahme zu schenken, dass Sie Sich uns zu einem ganz besonderen Danke verpflichtet haben, den wir Ihnen abzustatten uns gedrungen fühlen. Dabey dürfen wir uns zugleich der Hoffnung überlassen, dass Sie auch ferner fortfahren werden, unserer Gesellschaft und ihrer Sammlung Ihre geneigte Theilnahme und Unterstützung angedeihen zu lassen².

Han gjorde saavist heller ikke deres Forhaabninger til Skamme. Ikke blot var han i d. m. i Begyndelsen deres Agent i København, der sørgede for Fordelingen af deres Aarsberetninger og Opkrævning af Medlemskontingentet selv var han kontingentfri som Tak for en Samling Mønter, han havde foræret dem - men han stod dem ogsaa bi i videnskabelig Henseende. Først og fremmest da med sin rige Viden i middelalderlig Numismatik, saaledes som det fremgaar af hans talrige Breve til Flor ${ }^{3}$ og af to Afhandlinger om Møntfund i deres Aarsberetninger. Med en næsten faderlig Interesse fulgte han det nye Museums forste famlende Skridt: „Det har sine Vanskeligheder,“ siger han, „at faa Musæet frem, men disse vil overvindes, og om nogle Aar vil man ogsaa i Hertugdømmerne indsee Vigtigheden af en saadan Samling, og der vil indkomme mere til den $i$ en Maaned end nu i et Aar. "5 Foreløbig gik denne Spaa-

1 Udat. Koncept, der efter Indholdet maa være fra Slutn. af 1833 . W's Brev, paa hvilken den er Svar, er ikke bevaret. ${ }^{2}$ Skr. af $1835{ }^{25} /{ }^{2}{ }^{3} \mathrm{Kgl}$. Bibl. Ny kgl. Saml. $1766,2^{\circ}$.

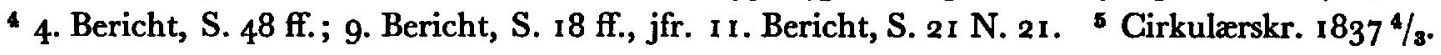


dom dog ikke i Opfyldelse. Tværtimod syntes Publikums Interesse at tage af, og saa meget gladere blev man i Kiel for en værdifuld Gave fra Kommissionen i I 845. Allerede tidligere havde man ved flere Lejligheder betænkt dem. I I835 havde man saaledes, forøvrig stik mod den gode gamle Regel, at et Fund ikke bør splittes, foræret dem et anseeligt Udvalg af et i Vaalse paa Falster gjort Sølvfund fra Oldtidens Slutning ${ }^{1}$, og da man $183^{6}$ „med sand Fornøjelse“ havde modtaget deres første Aarsberetning, kvitterede man for Modtagelsen ved at sende en paa Fyen funden Halsring fra Broncealderen og nogle Guldfingerringe. Endnu betydeligere var dog Gaven fra 1845. Den bestod i to kostelige Smykker fra Broncealderen, en i Nærheden af Kiel funden Guldring, en „Edsring“, som de dengang kaldtes, og et spiralformet Guldarmbaand fra Aabenraa Amt ${ }^{2}$. Et smukt Vidnesbyrd om Thomsens hele dybt forstaaende Tankegang er hans Udtalelse i det Cirkulære, hvormed han omsender Kielernes Takkebrev:

„Det har fornøiet mig ... at see, at de til Kiel oversendte Guldoldsager have fundet en udmærket god Modtagelse. Jeg erindrer meget vel, hvor haard en Prøve det var i Begyndelsen naar noget kostbart blev fundet, dette da forbeholdtes Kunstkammeret og alene de tilsyneladende mindre betydelige Sager bleve overladte til Commissionens Samling, som dengang omtrent stod paa samme Trin som den Kieler nu. "3

Og da Museets Erhvervelser i 1846 havde været meget magre - man „behøver desværre ikke at blive misundelig over de vigtige Oldsager, Samlingen er bleven forøget med", skriver han i et Cirkulære -, overvejer han, hvorledes man kunde komme dem lidt til Hjælp med Afstøbninger ${ }^{4}$.

Gaverne til Kiel viser tilfulde, at Thomsens Kolleger i Kommissionen delte hans Syn paa den yngre Samling; thi selvom han efterhaanden ubestridt stod som Kommissionens første Mand, var han dog ingenlunde eneraadende. Et godt Indblik i dens hele Indstilling overfor Museet i Kiel endnu saa sent som i Efteraaret 1847 giver Behandlingen af et gennem Rentekamrets tyske Afdeling indsendt Jordfund, det i Worsaaes "Nordiske Oldsager" som Nr. $5^{64}$ afbildede Sølvbeslag fra Oldtidens Slutning fra Helved paa Als (Mus. Nr. I4201). Thomsen erklærede det for „nyttigt og velkomment“ for Oldnordisk Museum, men ikke „af største Vigtighed “, og Formanden, Overhofmarskal Levetzau, foreslog derfor, at det efter Rentekamrets Henstilling skulde afgives til Kiel. Herimod pro-

1 1. Bericht, S. 42 f., 54. Jfr. Takkeskr. af $7 / 3$ I836. 2 1 I. Bericht, S. 9-1o. ' Cirkul. af 16/12 1845. Cirkul.skr. af 13/6 1847. Antagelig staar det i Forbindelse hermed, at Rafn 1847 sender nogle Afstøbninger - samt en Del indianske Pilespidser! (13. Bericht, S. 89). 
testerede imidlertid et andet af Kommissionens Medlemmer, den meget energiske Professor Rafn, men vel at mærke udelukkende af videnskabelige Grunde, da Stykket vilde komme bedre til sin Ret i København end i Kiel, som man i Stedet for skulde give „et eller to anseelige Stykker, Guldringe eller deslige“. „Thi“, fortsætter han, „det er vistnok i flere Henseender særdeles ønskeligt, at vi herfra viser, at vi interesserer os for de offentlige Samlinger i Kiel, og saavidt jeg skjønner staae vi os særdeles godt med disses Bestyrelse, hvilket venlige Forhold vi ville gjøre os Umage for at vedligeholde. " Af Frygt for, at det efterhaanden skulde blive Praxis - ("det er allerede skeet et Par Gange") - at Kiel skulde have alt Danefæ fra Slesvig ${ }^{1}$, sluttede Thomsen sig hertil, hvor meget han end „ønsker Samlingen i Kiel op“, og hvor vel han vidste, „hvor opmærksom man er paa alt, hvad der fra Hertugdømmerne kommer til Kjøbenhavn "2.

Kort efter blev Kommissionens velvillige Holdning overfor Kiel dog udsat for en ulige haardere Belastningsprøve. Det var ved Spørgsmaalet om den Jaspersenske Oldsagssamling, en Sag der fik en saa indgribende Betydning for dansk Museumshistorie, at den fortjener en særskilt Behandling, hvorfor den her kun skal omtales i al Korthed ${ }^{3}$. Selskabet i Kiel ønskede meget at erhverve den betydelige Samling af slesvigske Oldsager, der var tilvejebragt af den som Talsmand for det danske Sprog kendte, 1847 afdøde Justitsraad Cl. Jaspersen paa Nordskov i Angel, men da det ikke af sine egne Midler kunde klare de I6oo Rdlr., Enken forlangte, ansøgte det Kongen om Beløbet. Andragendet blev sendt til Kommissionens Erklæring, der imidlertid efter mange og lange Drøftelser endte med at indstille, at Samlingen skulde købes til Oldnordisk Museum, hvilket bifaldtes af Kongen. Den kgl. Resolution faldt d. 20. Marts.

1 I sin Approbation af Selskabets Statutter havde Kongen udfra Retsreglen i Jydske Lov forbeholdt sig Bestemmelsesretten over „Danefæ“, jordfundet Guld og Sølv, fra Slesvig - derimod naturligvis ikke fra Holsten, hvor Jydske Lov jo ikke gjaldt. Forholdet er nøjagtigt som i Kongeriget, hvor jordfundet Guld og Sølv dengang af de lokale Embedsmænd indsendtes til Rentekamret, der disponerede over det paa Kongens Vegne. Det er derfor ganske ugrundet, naar Professor Graef i sin Afhandling om Flensborgmuseet (Zeitschr. f. schl.-holst. Gesch. 58. Bd., S. 2) i denne Reservation ser et Tegn paa "die erwachende Spannung " mellem Dansk og Tysk, ligesom det er ganske ulogisk, naar han fortsætter, at Selskabet "trotzdem“ i den ikke saa nogen Hindring for "at optage hele Hertugdømmet Slesvig i sit Arbejdsomraade". Selskabet hed jo det slesvig-holstenske og var jo netop paa dansk Initia tiv stiftet for at tage sig af Oldsagerne i begge Hertugdømmer! 2 Efter Cirk. fra Okt. I847. ${ }^{3}$ De paagaldende Aktstykker findes dels i Museets Arkiv (J. Nr. i 848/4), dels i Assignationskontoret (J. Nr. 666/48) og Finansministeriets Forestillinger og Kgl. Resol. 1848 Nr. 53 i Rigsarkivet. Jeg haaber at kunne give en mere udførlig Fremstilling i et i Anl. af Nationalmuseets Nybygning paatænkt Skrift. 
Samme Aften afholdtes det berømte Kasinomøde, Dagen efter sejlede den slesvig-holstenske Deputation fra Kiel til København for at kræve Slesvigs Optagelse i det tyske Forbund, og en Uge senere stod de to Dele af Monarkiet i Vaaben mod hinanden. Man forstaar derfor godt, at der paa Finansdeputationens Koncept til Fru Jaspersen er noteret: „Maa beroe indtil roligere Tider i Angeln." Først efter Krigen gik Handelen i Orden, og Samlingen kom til at danne Grundstammen i den $185^{2}$ oprettede „Kgl. Samling af nordiske Oldsager" i Flensborg.

Gik Kommissionen end efter skarpe indre Brydninger mod Selskabets Andragende - antagelig fordi det under Sagens Behandling var bleven oplyst, at Jaspersen havde ønsket, at hans Samling kom til København - søgte man dog paa anden Vis at holde Kiel skadesløs. Ligesom man allerede tidligere, hedder det $\mathrm{i}$ Indstillingen til Finansdeputationen, „har afgivet ikke ubetydelige Bidrag til Samlingen i Kiel“, „saaledes havde man, forinden denne Sag tilstilledes Commissionen til Betænkning, vedtaget i Løbet af tilstundende Sommer, naar Museet her havde erholdt de af Kunstmuseets antiquariske Samlinger, som ifølge kongelig Resolution dertil skulle afgives, da at oversende til Samlingen i Kiel en større Suite af værdifulde Oldsager. Men forsaavidt den kongelige Finansdeputation maatte tiltræde og Hans Majestæt Kongen allernaadigst approbere Commissionens Forslag ... vil Commissionen, naar det herværende Museums Omflytning er tilendebragt, oversende til Samlingen i Kiel en endnu værdifuldere Suite af Oldsager end den allerede tilsigtede, og deriblandt flere af Guld.“ Det er altsaa Thomsens I833 bebudede „Fangst“" (jfr. ovfr. S. 99), der nu skulde blive til Virkelighed. Den strandede i Tidens Storme, men om den vilde have tilfredsstillet Kielerne, er vel tvivlsomt. Til Gengæld fik de en halv Menneskealder senere ikke blot den Jaspersenske Samling, men adskilligt mere, nemlig hele Flensborgsamlingen - Nydambaaden inclusive. 